GRASAS Y ACEITES 72 (1)

January-March 2021, e400

ISSN-L: 0017-3495

https://doi.org/10.3989/gya.1262192

\title{
New insights into the antifungal activity of lactic acid bacteria isolated from different food matrices
}

\author{
(F. Panebianco and ${ }^{\circledR}$ A. Caridi ${ }^{\varpi}$ \\ Department of AGRARIA, "Mediterranea” University of Reggio Calabria, Via Feo di Vito, 89122 Reggio Calabria. Italy. \\ ${ }^{\circledR}$ Corresponding author: acaridi@unirc.it
}

Submitted: December 25, 2019; Accepted: March 02, 2020; Published online: March 03, 2021

\begin{abstract}
SUMMARY: The anti-mold activity of 397 strains of lactic acid bacteria was evaluated using both the spot method in Petri plates and coculture in liquid medium. The study led to the selection of 34 strains isolated from table olives or olive brines, 15 strains from dairy products, and 10 strains from sourdoughs, all able to inhibit a strain of Penicillium crustosum and/or a strain of Aspergillus section Nidulantes, prevailing in two Calabrian olive brines. Seven representative strains were identified as Lactobacillus pentosus (four strains) and Lactobacillus sanfranciscensis (three strains) and are currently under testing for their antifungal activity during table olive fermentation. This research constitutes an initial contribution to the control of fungal growth and mycotoxin accumulation during table olive fermentation. The selected strains could be used as adjunct cultures in table olive fermentation, allowing for the biological control of table olive safety.
\end{abstract}

KEYWORDS: Antifungal activity; Aspergillus section Nidulantes; Lactic acid bacteria; Penicillium; Table olive fermentation

RESUMEN: Nuevos conocimientos sobre la actividad antifúngica de las bacterias del ácido láctico aisladas de diferentes matrices alimentarias. La actividad antimoho de 397 bacterias del ácido láctico se evaluó utilizando tanto el método puntual en placas de Petri como el co-cultivo en medio líquido. El estudio condujo a la selección de 34 cepas aisladas de aceitunas de mesa o salmueras de oliva, 15 cepas de productos lácteos y 10 cepas de masa madre, todas capaces de inhibir una cepa de Penicillium crustosum y/o una cepa de Aspergillus sección Nidulantes, que prevalecen en dos salmueras de aceituna de Calabria. Se identificaron siete cepas representativas como Lactobacillus pentosus (cuatro cepas) y Lactobacillus sanfranciscensis (tres cepas) y actualmente se están probando su actividad antifúngica durante la fermentación de aceituna de mesa. Esta investigación constituye una primera contribución para controlar el crecimiento de hongos y la acumulación de micotoxinas durante la fermentación de aceitunas de mesa. Las cepas seleccionadas podrían usarse como cultivos adjuntos en la fermentación de aceitunas de mesa.

PALABRAS CLAVE: Actividad antifúngica; Aspergillus sección Nidulantes; Bacterias de ácido láctico; Fermentación de aceituna de mesa; Penicillium

Citation/Cómo citar este artículo: Panebianco F, Caridi A. 2021. New insights into the antifungal activity of lactic acid bacteria isolated from different food matrices. Grasas Aceites 72 (1), e400. https://doi.org/10.3989/gya.1262192

Copyright: (C2021 CSIC. This is an open-access article distributed under the terms of the Creative Commons Attribution 4.0 International (CC BY 4.0) License. 


\section{INTRODUCTION}

In Mediterranean countries, table olives are among the most commonly consumed fermented food. They are considered a functional food due to their nutritional value, content in bioactive compounds and dietary fiber, fatty acid composition and presence of several antioxidants (Campus et al., 2018).

In table olive fermentation, mold growth can cause huge economic losses and reduce the product safety (El Adlouni et al., 2006; Ghitakou et al., 2006). Molds of the genera Aspergillus and Penicillium have been described in different olive fermentation processes (Heperkan et al., 2006) and both are considered undesirable microorganisms. They can produce mycotoxins and cause the softening of fruits because of their cellulase and xylanase activities (Arroyo-López et al., 2016). Penicillium crustosum is one of the most prevalent molds in fermented black table olives and is able to produce toxic metabolites such as dehydrocyclopeptin, andrastin A, cyclopenol, penitrem A, roquefortine $\mathrm{C}$, viridicatol (Bavaro et al., 2017) and thomitrem A and E (Rundberget and Wilkins, 2002). Aspergillus section Nidulantes includes several species able to produce mycotoxins, like aflatoxins, sterigmatocystin, emestrin, fumitremorgins, asteltoxins, and paxillin; four species (A. astellatus, A. miraensis, A. olivicola, A. venezuelensis) produce aflatoxin $\mathrm{B} 1$ (Chen et al., 2016).

Different chemical, physical and biological methods have been proposed to prevent mold growth or to eliminate or reduce aflatoxins during table olive fermentation. For example, the spoilage of table olive by molds can be reduced using chemical preservatives, such as potassium sorbate and sodium benzoate (Turantaş et al., 1999) or natamycin (Hondrodimou et al., 2011). Değirmencioğlu et al. (2014) studied the effect of washing solutions -acetic acid, lactic acid, chlorine dioxide- on dry-salted olives during 7 months of storage at $4{ }^{\circ} \mathrm{C}$. The chlorine dioxide solution $(10 \mathrm{ppm})$ combined with vacuum packaging was the best approach for controlling mold and yeast growth. In addition, the effectiveness of high hydrostatic pressures and citrinin against mold growth in table olives has been demonstrated (Tokuşoğlu et al., 2010; Argyri et al., 2014).

In view of growing consumer concern for food safety issues, including additive content (Bearth et al., 2014), the food industry is seeking biological alternatives in order to inhibit undesirable molds. Among the novel approaches, biopreservation and, more specifically, the selection of protective cultures has been identified as one of the more promising alternatives.

It is well known that lactic acid bacteria (LAB) can produce several antifungal metabolites (Schnürer and Magnusson, 2005). LAB are able to inhibit molds related to bread spoilage (Corsetti et al., 1998); consequently, the use of antifungal sourdough in the bakery industry is now a common practice to ensure the microbiological safety of bread (Gerez et al., 2009). Antifungal lactobacilli can also be found in raw milk (Delavenne et al., 2012); therefore, specifically selected LAB strains can also be used as biopreservatives in fresh cheeses (Fernandez et al., 2017). The antifungal activity of LAB, specifically Lactobacillus plantarum, and their ability to reduce aflatoxin B1 during olive storage has also been demonstrated (Kachouri et al., 2014).

Considering the state of the art, the aim of the present study was to find $\mathrm{LAB}$ able to inhibit molds commonly associated with table olive fermentation and spoilage.

\section{MATERIALS AND METHODS}

\subsection{Microorganisms}

Three hundred ninety-seven strains of LAB from the Collection of the Laboratory of Microbiology (Department of Agraria, Mediterranea University of Reggio Calabria, Reggio Calabria, Italy) were used. All the strains were previously classified to genus level, according to Cogan et al., (1997). Each strain was tested for its Gram reaction, catalase using $3 \mathrm{~g}$ $\mathrm{H}_{2} \mathrm{O}_{2} / \mathrm{L}$, shape by observation of overnight cultures using a phase contrast microscope Standard 20 (Carl Zeiss, Göttingen, Germany), and for the heterofermentation or homofermentation of sugars (Abd-el-Malek and Gibson, 1948). The growth of coccal-shaped bacteria was examined in M17 broth after incubation at $10{ }^{\circ} \mathrm{C}$ for 7 days, at $45{ }^{\circ} \mathrm{C}$ for 2 days, and in M17 broth containing 20,40, and $65 \mathrm{~g} \mathrm{NaCl} / \mathrm{L}$ after incubation at $30^{\circ} \mathrm{C}$ for 4 days. The LAB was tested against two mold strains -one Penicillium and one Aspergillus- prevailing in two different Calabrian olive brines. Penicillium was identified as Penicillium crustosum according to 
Visagie et al., (2014); Aspergillus was included in the section Nidulantes according to Chen et al., (2016). Out the 397 strains of LAB, 198 strains were isolated from table olives or olive brines, 115 strains from dairy products, and 84 strains from sourdough.

Finally, the seven more representative LAB were identified as Lactobacillus pentosus (four strains) and Lactobacillus sanfranciscensis (three strains) by molecular methods. DNA was extracted by the InstaGene matrix (Bio-Rad) from $\mathrm{LAB}$ and subjected to amplification using specific primers (Young et al., 1991). LAB identification was performed with PCR-ARDRA, comparing the profile isolates to those previously described in the literature and to International Collection reference strains (Aquilanti et al., 2007; Torriani et al., 2001).

\subsection{Preliminary screening}

The LAB were screened for their antagonistic activity using the agar spot method (Spelhaug and Harlander, 1989) with some modifications. All the strains were stored at $-80{ }^{\circ} \mathrm{C}$ using a cryopreservative bead storage system Microbank TM (Pro-Lab Diagnostics, Canada). The LAB were cultured in a deMan Rogosa Sharpe (MRS) broth at $30{ }^{\circ} \mathrm{C}$ for 48 hours. Subsequently, $0.1 \mathrm{ml}$ of each culture were inoculated in MRS agar plates $(60 \mathrm{~mm})$, incubated at $30{ }^{\circ} \mathrm{C}$ for 48 hours. For each strain, the biomass was collected using a sterile loop and spotted in triplicate in MRS agar plates $(90 \mathrm{~mm})$. Then, the plates were overlaid with $10 \mathrm{ml}$ of Yeast Extract Peptone Dextrose agar (agar $0.7 \%$ ) containing $0.1 \mathrm{ml}$ of an abundant spore suspension of each mold. After $72 \mathrm{~h}$ at $30{ }^{\circ} \mathrm{C}$, the plates were checked for the presence of inhibition zones around the spots of each LAB.

\subsection{Test for antifungal activity of LAB by co-cul- ture in a liquid medium}

The LAB that exhibited antagonistic activity with the agar spot method were tested by coculture in a liquid medium against three serial dilutions of spore suspensions of the two molds. Penicillium crustosum and Aspergillus section Nidulantes were inoculated in MRS agar plates and incubated at $30{ }^{\circ} \mathrm{C}$ for $48 \mathrm{~h}$ in order to test their ability to grow in this medium and adapt them to the subsequent conditions. Spore suspensions were prepared from the same plates as described above and diluted at 1:10, 1:100 and 1:1000 in sterile physiological solution. Cocultures were prepared by inoculating $0.1 \mathrm{ml}$ of pre-culture of each LAB in tubes containing $10 \mathrm{ml}$ of MRS broth; $0.1 \mathrm{ml}$ of each dilution of the spore suspensions was added. The tubes were incubated at room temperature for sixteen days and the antagonistic activity was evaluated based on the absence of mold growth at the top of the MRS broth.

\section{RESULTS}

\subsection{Preliminary screening}

One hundred and fifteen strains $(28.97 \%$ of the total strains tested) exhibited antagonistic activity in the agar spot method: 60 strains isolated from table olives or olive brines, 20 dairy strains and 35 sourdough strains. The strains which were isolated from the same sample, exhibited the same cellular morphology, and showed an identical antagonistic activity were considered duplicates. Consequently, the 115 strains were reduced to 59:34 strains isolated from table olives or olive brines (listed in Table 1), 15 dairy strains (listed in Table 2), and 10 sourdough strains (listed in Table 3).

\subsection{Test for antifungal activity of LAB by co-cul- ture in a liquid medium}

The antagonistic activity of the 59 pre-selected strains of $\mathrm{LAB}$ against the two molds was studied by co-culture in a liquid medium at three different concentrations of the two molds; all strains exhibited good antagonistic activity against one or both tested molds (Figure 1). When the LAB were inoculated together with the less diluted spore suspensions $(1: 10), 58$ strains $(98.3 \%$ of all 59 LAB) exhibited antagonistic activity against Penicillium crustosum and 57 (96.6\% of all 59 LAB) against Aspergillus section Nidulantes after sixteen days. All the LAB strains were able to inhibit the growth of Penicillium crustosum at the spore suspension $1: 100 ; 58$ strains $(98.3 \%$ of all $59 \mathrm{LAB}$ ) inhibited the growth of Aspergillus section Nidulantes at the same concentration. All the $\mathrm{LAB}$ tested inhibited the growth of both molds at the most diluted $(1: 1000)$ spore suspensions after sixteen days. 
TABLE 1. List of the 34 lactic acid bacteria isolated from olives and exhibiting antagonistic activity

\begin{tabular}{|c|c|c|c|c|}
\hline \multicolumn{3}{|c|}{ Lactic acid bacteria } & \multicolumn{2}{|c|}{ Activity against olive moulds } \\
\hline Strain & Sample & First identification & Penicillium spp. & Aspergillus spp. \\
\hline B 200 & Olive_1 & Lactobacillus spp. & + & - \\
\hline B 212 & Olive brine_18 & Lactobacillus spp. & + & - \\
\hline B 221 & Olive_2 & Lactobacillus spp. & + & - \\
\hline В 229 & Olive_16 & Lactobacillus spp. & + & - \\
\hline B 248 & Olive brine_5 & Lactobacillus spp. & + & - \\
\hline B 283 & Olive brine_13 & Lactobacillus spp. & - & + \\
\hline B 284 & Olive_14 & Lactobacillus spp. & - & + \\
\hline B 318 & Olive brine_12 & Lactobacillus spp. & + & - \\
\hline В 337 & Olive brine_11 & Lactobacillus spp. & + & - \\
\hline B 348 & Olive_2015_C_15gg & Lactobacillus spp. & + & - \\
\hline B 350 & Olive_2015_D_15gg & Lactobacillus spp. & + & - \\
\hline B 354 & Olive_2015_E_15gg & Lactobacillus spp. & + & - \\
\hline B 358 & Olive_2015_G_15gg & Lactobacillus spp. & + & - \\
\hline В 364 & Olive_2015_L_15gg & Lactobacillus spp. & + & - \\
\hline В 366 & Olive_2015_N_15gg & Lactobacillus spp. & + & + \\
\hline B 384 & Olive_2015_B_30gg & Lactobacillus spp. & + & - \\
\hline В 386 & Olive_2015_C_30gg & Lactobacillus spp. & - & + \\
\hline В 389 & Olive_2015_D_30gg & Lactobacillus spp. & + & + \\
\hline В 391 & Olive brine_MF3_67gg & Lactobacillus spp. & + & + \\
\hline B 524 & Olive_2015_G1_240gg & Lactobacillus spp. & + & - \\
\hline B 525 & Olive_2015_G2_240gg & Lactobacillus spp. & + & - \\
\hline B 526 & Olive_2015_H1_240gg & Lactobacillus spp. & + & - \\
\hline B 527 & Olive_2015_H2_240gg & Lactobacillus spp. & + & - \\
\hline В 529 & Olive_2015_I1_240gg & Lactobacillus spp. & + & - \\
\hline B 531 & Olive_2015_L1_240gg & Lactobacillus spp. & + & - \\
\hline B 534 & Olive_2015_M1_240gg & Lactobacillus spp. & + & - \\
\hline В 536 & Olive_2015_N1_240gg & Lactobacillus spp. & + & - \\
\hline В 539 & Olive_2015_O1_240gg & Lactobacillus spp. & + & - \\
\hline B 540 & Olive_2015_O2_240gg & Lactobacillus spp. & + & - \\
\hline B 542 & Olive_2015_E1_240gg & Lactobacillus spp. & + & - \\
\hline B 543 & Olive_2015_M1_240gg & Lactobacillus spp. & + & - \\
\hline B 545 & Olive_2015_D1_240gg & Lactobacillus spp. & + & - \\
\hline B 546 & Olive_2015_B1_240gg & Lactobacillus spp. & + & - \\
\hline B 560 & Olive brine_2016 & Lactobacillus spp. & + & - \\
\hline
\end{tabular}




\subsection{LAB identification}

Among the 34 LAB listed in Table 1, 91.2\% of them exhibited antagonistic activity against Penicillium crustosum but only $17.6 \%$ exhibited antagonistic activity against Aspergillus section Nidulantes. The following three strains are representative of the three typologies of behavior against the two molds:

- strain B221, identified as Lactobacillus pentosus, which exhibited antagonistic activity against Penicillium crustosum.

- strain B283, identified as Lactobacillus pentosus, which exhibited antagonistic activity against Aspergillus section Nidulantes.

- strain B391, identified as Lactobacillus pentosus, which exhibited antagonistic activity against both strains of mold.

All 15 LAB listed in Table 2 exhibited antagonistic activity against Penicillium crustosum but none of them exhibited antagonistic activity against Aspergillus section Nidulantes. The strain B167, identified as Lactobacillus pentosus, is representative of this typology of behavior against the two molds.

Among the $10 \mathrm{LAB}$ listed in Table 3, 90\% exhibited antagonistic activity against Penicillium crustosum but only $10 \%$ exhibited antagonistic activity against Aspergillus section Nidulantes. The following three strains are representative of the three typologies of behavior against the two molds:

1. Strain B426, identified as Lactobacillus sanfranciscensis, which exhibited antagonistic activity against Penicillium crustosum.

2. Strain B551, identified as Lactobacillus sanfranciscensis, which exhibited antagonistic activity against the strain of Aspergillus section Nidulantes.

3. Strain B511, identified as Lactobacillus sanfranciscensis, which exhibited antagonistic activity against both strains of mold.

The seven representative strains of LAB are currently under testing for their antifungal activity during table olive fermentation (unpublished data).

\section{DISCUSSION}

In the present study, 59 LAB exhibited antifungal activity. Both in agar and in co-culture, the LAB exhibited greater inhibitory activity against Penicillium crustosum compared to Aspergillus section Nidulantes. The antifungal

TABLE 2 . List of the 15 dairy lactic acid bacteria exhibiting antagonistic activity

\begin{tabular}{ccccc}
\hline & Lactic acid bacteria & & \multicolumn{2}{c}{ Activity against olive moulds } \\
\hline Strain & Sample & First identification & Penicillium spp. & Aspergillus spp. \\
\hline B 3 & PP_A03_1 & Lactobacillus spp. & + & - \\
B 15 & PP_M3 & Lactobacillus spp. & + & - \\
B 17 & PP_P4 & Lactobacillus spp. & + & - \\
B 27 & PP_A03_2 & Lactobacillus spp. & + & - \\
B 28 & PP_A03_3 & Lactobacillus spp. & + & - \\
B 54 & UK_TH1 & Lactobacillus spp. & + & - \\
B 59 & UK_SR1 & Lactobacillus spp. & + & - \\
B 62 & UK_WB1 & Lactobacillus spp. & + & - \\
B 76 & RAF_M1 & Lactobacillus spp. & + & - \\
B 79 & PM_M2 & Lactobacillus spp. & + & - \\
B 147 & M_DN1 & Lactobacillus spp. & + & - \\
B 164 & M_FP1 & Lactobacillus spp. & + & - \\
B 167 & P_M3 & Lactobacillus spp. & + & - \\
B 172 & CC_4 & Lactobacillus spp. & + \\
B 179 & MC_5 & Lactobacillus spp. & + & - \\
\hline
\end{tabular}


TABLE 3. List of the 10 lactic acid bacteria isolated from sourdough and exhibiting antagonistic activity

\begin{tabular}{cllcc}
\hline & \multicolumn{2}{c}{ Lactic acid bacteria } & \multicolumn{2}{c}{ Activity against olive moulds } \\
\hline Strain & \multicolumn{1}{c}{ Sample } & First identification & Penicillium spp. & Aspergillus spp. \\
\hline B 426 & Sourdough_SC_SA1 & Lactobacillus spp. & + & - \\
B 435 & Sourdough_CL_IF1 & Leuconostoc spp. & + & - \\
B 455 & Sourdough_CL_IF2 & Lactobacillus spp. & + & - \\
B 470 & Sourdough_CZ_IFAL1 & Pediococcus spp. & + & - \\
B 481 & Sourdough_CZ_IFAL2 & Lactobacillus spp. & + & - \\
B 489 & Sourdough_RC_LSDMA1 & Lactobacillus spp. & + & - \\
B 503 & Sourdough_VV_CF1 & Lactobacillus spp. & + & - \\
B 511 & Sourdough_GI_C1 & Lactobacillus spp. & + & + \\
B 551 & Sourdough_VV_SF1 & Lactobacillus spp. & - & + \\
B 553 & Sourdough_VV_LS1 & Lactobacillus spp. & + & - \\
\hline
\end{tabular}

LAB strains so identified belong to two species (Lactobacillus pentosus and Lactobacillus sanfranciscensis), whose ability to inhibit or reduce mold growth is well known (Corsetti et al., 1998; Schnürer and Magnusson, 2005).

The antifungal activity of LAB is related to their ability to produce antifungal metabolites, e.g. organic acids, proteinaceous compounds, reuterin, and 3-hydroxylated fatty acids (Schnürer and Magnusson, 2005). For example, the inhibitory properties of phenyllactic acid (PLA) produced by $\mathrm{LAB}$ against several fungal species isolated from food have been demonstrated (Valerio et al., 2004). Regarding proteinaceous compounds, bacteriocin-producing LAB were already isolated from fermented olives and it was observed that their ability to produce bacteriocins was affected by $\mathrm{NaCl}, \mathrm{pH}$ and temperature (Hurtado et al., 2011). Moreover, the bacteriocin production by LAB seemed to be affected by the presence of other bacteria during olive fermentation (Ruiz-Barba et al., 2010).

The antifungal activity of LAB could also be due to a synergic effect between the sodium acetate present in the MRS medium and lactic acid and other compounds produced by LAB (Cabo et al., 2002). Schillinger and Villareal (2010) demonstrated how sodium acetate in a culture medium can influence the inhibitory activity of LAB; in their experiment, LAB which exhibited antifungal activity in MRS agar with sodium acetate did not have the capacity to inhibit molds in MRS agar without sodium acetate. Also, Cheong et al., (2014) reported that LAB which exhibited antifungal activity in MRS agar with sodium acetate did not exhibit the same behavior in MRS agar without sodium acetate; however, the same strains were able to inhibit Penicillium commune in cottage cheese.

Lind et al., (2005) demonstrated how the absence of sodium acetate in MRS agar did not influence the antifungal activity of Propionibacterium against Penicillium roqueforti and Aspergillus fumigatus. Magnusson et al., (2003) performed an HPLC analysis of the supernatants of the LAB exhibiting antifungal activity, previously tested in MRS broth, and the concentration of lactic acid was equal to or even higher than concentrations in strains devoid of inhibitory activity; in addition, the concentration of acetic acid was similar to that found in MRS broth. This demonstrated that the activity was probably due to the production of other antifungal compounds.

In the present study we decided to carry out the tests using MRS with sodium acetate. Penicillium crustosum and Aspergillus section Nidulantes grew well in all the control samples, so the inhibition was probably due to the production of antifungal substances by LAB.

\section{CONCLUSIONS}

In our opinion, this study makes a useful contribution to solving the problem of fungal growth and potential mycotoxin accumulation during table olive fermentation, thereby improving its safety. 
Spore suspension 1:10

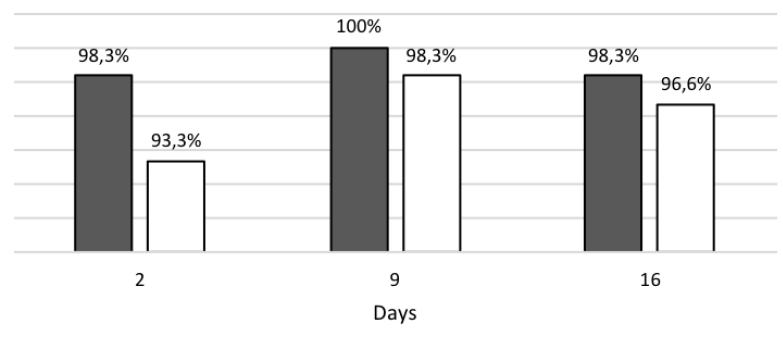

口LAB active against Penicillium crustosum

口LAB active against Aspergillus section Nidul antes
Spore suspension 1:100

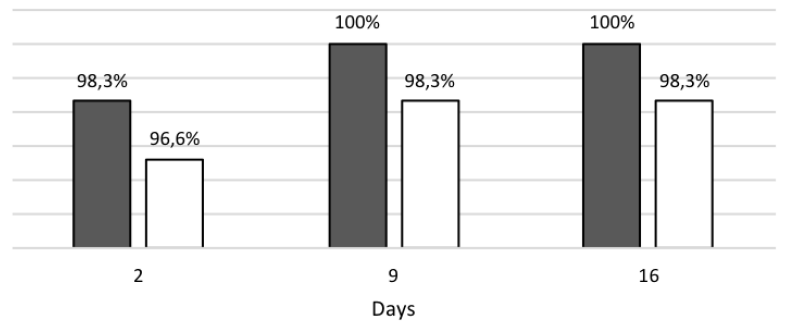

口LAB active against Penicillium crustosum

口LAB active against Aspergillus section Nidul antes

Spore suspension 1:1000

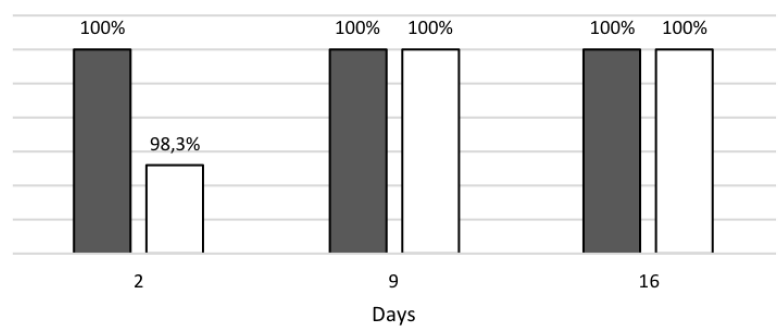

口LAB active against Penicillium crustosum

DLAB active against Aspergillus section Nidulantes

FIGURE 1. Percentage of the selected 59 strains of lactic acid bacteria that confirmed their activity against Penicillium crustosum in liquid medium co-culture $(\square)$ and Aspergillus section Nidulantes $(\square)$ at the three concentrations of spore suspension.

\section{Summarizing:}

Almost 400 strains of LAB were screened for anti-mold activity.

One strain of Penicillium crustosum and one strain of Aspergillus section Nidulantes were used;

Almost 60 strains of LAB resulted in the ability to inhibit one or both molds.

The antagonistic activity was evaluated both using the spot method and by co-culture in liquid medium.

Starting from the present results, a consortium of the best anti-mold LAB could be tested in table olive fermentation.

\section{ACKNOWLEDGMENTS}

This work was supported by PON 03 PE_00090_2 - Modelli sostenibili e nuove tecnologie per la valorizzazione delle olive $e$ dell'olio extra vergine di oliva prodotto in Calabria and by POR Calabria FESR 2007/2013 1.1.1.2 Nuove tecnologie per la valorizzazione della filiera delle conserve: CONSERVO.

\section{REFERENCES}

Abd-el-Malek Y, Gibson T. 1948. Studies in the bacteriology of milk: I. The streptococci of milk. J. Dairy Res. 15, 233-248. https:// doi.org/10.1017/S0022029900005082

Aquilanti L, Silvestri G, Zannini E, Osimani A, Santarelli S, Clementi F. 2007. Phenotypic, genotypic and technological characterization of predominant lactic acid bacteria in Pecorino cheese from central Italy. J. Appl. Microbiol. 103, 948-960. https://doi.org/10.1111/j.1365 $-2672.2007 .03513 . x$

Argyri AA, Panagou EZ, Nychas G-JE, Tassou CC. 2014. Nonthermal pasteurization of fermented green table olives by means of high hydrostatic pressure processing. Biomed. Res. Int. ID 515623. https://doi.org/10.1155/20 $14 / 515623$

Arroyo-López FN, Medina E, Ruiz-Bellido MÁ, Romero-Gil V, Montes-Borrego M, Landa BB. 2016. Enhancement of the knowledge on fungal communities in directly brined Aloreña de Málaga green olive fermentations by metabarcoding analysis. PLoS One 11 (9), e0163135. https://doi.org/10.1371/journal.po ne.0163135 
Bavaro SL, Susca A, Frisvad JC, Tufariello M, Chytiri A, Perrone G, Mita G, Logrieco AF, Bleve G. 2017. Isolation, characterization, and selection of molds associated to fermented black table olives. Front. Microbiol. https:// doi.org/10.3389/fmicb.2017.01356

Bearth A, Cousin ME, Siegrist M. 2014. The consumer's perception of artificial food additives: Influences on acceptance, risk and benefit perceptions. Food Qual. Prefer. 38, 14-23. https://doi.org/10.1016/j.foodqual.20 14.05.008

Cabo ML, Braber AF, Koenraad PM. 2002. Apparent antifungal activity of several lactic acid bacteria against Penicillium discolor is due to acetic acid in the medium. J. Food Prot. 65, 1309-1316. https://doi.org/10.4315/0362028x-65.8.1309

Campus M, Değirmencioğlu N, Comunian R. 2018. Technologies and trends to improve table olive quality and safety. Front. Microbiol. https://doi.org/10.3389/fmicb.2018.00617

Chen AJ, Frisvad JC, Sun BD, Varga J, Kocsubé S, Dijksterhuis J, Kim DH, Hong SB, Houbraken J, Samson RA. 2016. Aspergillus section Nidulantes (formerly Emericella): polyphasic taxonomy, chemistry and biology. Stud. Mycol. 84, 1-118. https://doi.org/ 10.1016/j.simyco.2016.10.001

Cheong EYL, Sandhu A, Jayabalan J, Le TTK, Nhiep NT, Ho HTM, Zwielehner J, Bansal N, Turner MS. 2014. Isolation of lactic acid bacteria with antifungal activity against the common cheese spoilage mould Penicillium commune and their potential as biopreservatives in cheese. Food Control 46, 91-97.

Cogan TM, Barbosa M, Beuvier E, BianchiSalvadori B, Cocconcelli PS, Fernandes I, Gomez J, Gomez R, Kalantzopoulos G, Ledda A, Medina M, Rea MC, Rodriguez E. 1997. Characterization of the lactic acid bacteria in artisanal products. J. Dairy Res. 64, 409-421. https://doi.org/10.1017/S0022029997002185

Corsetti A, Gobbetti M, Rossi J, Damiani P. 1998. Antimould activity of sourdough lactic acid bacteria: identification of a mixture of organic acids produced by Lactobacillus sanfrancisco CB1. Appl. Microbiol. Biotechnol. 50, 253-256. https://doi.org/10.1007/s0025300 51285

Değirmencioğlu N, Gürbüz $O$, Değirmencioğlu A, Yildiz S. 2014. Effect of pretreatments on microbial growth and sensory properties of dry-salted olives. J. Food Prot. 77, 1527-1537. https://doi.org/10.4315/0362-028X.JFP-14-036

Delavenne E, Mounier J, Déniel F, Barbier G, Le Blay G. 2012. Biodiversity of antifungal lactic acid bacteria isolated from raw milk samples from cow, ewe and goat over one-year period. Int. J. Food Microbiol. 155, 185-190. https:// doi.org/10.1016/j.ijfoodmicro.2012.02.003

El Adlouni C, Tozlovanu M, Naman F, Faid M, Pfohl-Leszkowicz A. 2006. Preliminary data on the presence of mycotoxins (ochratoxin A, citrinin and aflatoxin B1) in black table olives "Greek style" of Moroccan origin. Mol. Nutr. Food Res. 50, 507-512. https://doi.org/ 10.1002/mnfr.200600055

Fernandez B, Vimont A, Desfossés-Foucault E, Daga M, Arora G, Fliss I. 2017. Antifungal activity of lactic and propionic acid bacteria and their potential as protective culture in cottage cheese. Food Control 78, 350-356. https://doi.org/10.1016/j.foodcont.2017.03.007

Gerez CL, Torino MI, Rollán G, Font de Valdez G. 2009. Prevention of bread mould spoilage by using lactic acid bacteria with antifungal properties. Food Control 20, 144-148. https:// doi.org/10.1016/j.foodcont.2008.03.005

Ghitakou S, Koutras K, Kanellou E, Markaki P. 2006. Study of aflatoxin $B_{1}$ and ochratoxin A production by natural microflora and Aspergillus parasiticus in black and green olives of Greek origin. Food Microbiol. 23, 612-621. https://doi.org/10.1016/j.fm.2005. 12.008

Heperkan D, Meric BE, Sismanoglu G, Dalkiliç G, Güler FK. 2006. Mycobiota, mycotoxigenic fungi, and citrinin production in black olives. Adv. Exp. Med. Biol. 571, 203-210. https:// doi.org/10.1007/0-387-28391-9_13

Hondrodimou O, Kourkoutas Y, Panagou EZ. 2011. Efficacy of natamycin to control fungal growth in natural black olive fermentation. Food Microbiol. 28, 621-627. https://doi.org/ 10.1016/j.fm.2010.11.015

Hurtado A, Ben Othman N, Hamdi M, Ferrer S, Reguant C, Bordons A, Rozès N. 2011. Characterization of Lactobacillus isolates from fermented olives and their bacteriocin gene profiles. Food Microbiol. 28, 1514-1518. https://doi.org/10.1016/j.fm.2011.07.010

Kachouri F, Ksontini H, Hamdi M. 2014. Removal of aflatoxin B1 and inhibition of Aspergillus flavus growth by the use of Lactobacillus plantarum on olives. J. Food Prot. 77, 1760-1767. https://doi.org/10.4315/ 0362-028X.JFP-13-360 
Lind H, Jonsson H, Schnürer J. 2005. Antifungal effect of dairy propionibacteria - contribute on of organic acids. Int. J. Food Microbiol. 98, 157-165. https://doi.org/10.1016/j.ijfoodmic ro.2004.05.020

Magnusson J, Ström K, Roos S, Sjögren J, Schnürer J. 2003. Broad and complex antifungal activity among environmental isolates of lactic acid bacteria. FEMS Microbiol. Lett. 219, 129-135. https://doi.org/ 10.1016/S0378-1097(02)01207-7

Ruiz-Barba JL, Caballero-Guerrero B, Maldonado-Barragán A, Jiménez-Díaz R. 2010. Coculture with specific bacteria enhances survival of Lactobacillus plantarum $\mathrm{NC} 8$, an autoinducer-regulated bacteriocins producer, in olive fermentations. Food Microbiol. 27, 413-417. https://doi.org/10. 1016/j.fm.2009.10.002

Rundberget T, Wilkins AL. 2002. Thomitrems A and E, two indole-alkaloid isoprenoids from Penicillium crustosum Thom. Phytochemistry 61, 979-985. https://doi.org/10.1016/s0031-94 22(02)00369-2

Schillinger U, Villarreal JV. 2010. Inhibition of Penicillium nordicum in MRS medium by lactic acid bacteria isolated from foods. Food Control 21, 107-111. https://doi.org/10.1016/ j.foodcont.2008.11.010

Schnürer J, Magnusson J. 2005. Antifungal lactic acid bacteria as biopreservatives. Trends Food Sci. Technol. 16, 70-78. https://doi.org/ 10.1016/j.tifs.2004.02.014

Spelhaug SR, Harlander SK. 1989. Inhibition of foodborne bacterial pathogens by bacteriocins from Lactococcus lactis and Pediococcus pentosaceus. J. Food Prot. 52, 856-862. https://doi.org/10.4315/0362-028X-52.12.856

Tokuşoğlu Ö, Alpas H, Bozoğlu F. 2010. High hydrostatic pressure effects on mold flora, citrinin mycotoxin, hydroxytyrosol, oleuropein phenolics and antioxidant activity of black table olives. Innov. Food Sci. Emerg. Technol. 11, 250-258. https://doi.org/10.1016/j.ifset.20 09.11 .005

Torriani S, Felis GE, Dellaglio F. 2001. Differentiation of Lactobacillus plantarum, $L$. pentosus, and L. paraplantarum by recA gene sequence analysis and multiplex PCR assay with recA gene-derived primers. Appl. Environ. Microbiol. 67, 3450-3454. https:// doi.org/10.1128\%2FAEM.67.8.3450-3454.20 01

Turantaş F, Göksungur Y, Dinçer AH, Ünlütürk A, Güvenç U, Zorlu N. 1999. Effect of potassium sorbate and sodium benzoate on microbial population and fermentation of black olives. J. Sci. Food Agric. 79, 1197-1202. https://doi.org/10.1002/(SICI)1097-0010(1999 0701)79:9\%3C1197::AID-JSFA349\%3E3.0.C $\mathrm{O} ; 2-\mathrm{A}$

Valerio F, Lavermicocca P, Pascale M, Visconti A. 2004. Production of phenyllactic acid by lactic acid bacteria: an approach to the selection of strains contributing to food quality and preservation. FEMS Microbiol. Lett. 233, 289-295. https://doi.org/10.1016/ j.femsle.2004 .02.020

Visagie CM, Houbraken J, Frisvad JC, Hong S-B, Klaassen CHW, Perrone G, Seifert KA, Varga J, Yaguchi T, Samson RA. 2014. Identification and nomenclature of the genus Penicillium. Stud. Mycol. 78, 343-371. https://doi.org/ 10.1016/j.simyco.2014.09.001

Young JPW, Downer HL, Eardly BD. 1991. Phylogeny of the phototrophic rhizobium strain BTAi1 by polymerase chain reaction-based sequencing of a $16 \mathrm{~S}$ rRNA gene segment. $J$. Bacteriol. 173, 2271-2277. https://doi.org/ 10.1128\%2Fjb.173.7.2271-2277.1991 